\title{
BUDAYA KONSUMERISME DI KALANGAN MAHASISWA UNIVERSITAS NEGERI MEDAN PRODI PENDIDIKAN EKONOMI STAMBUK 2018
}

\author{
Dwi Wulandari ${ }^{1}$, Fila Destia Dinanti ${ }^{2}$, Intan Permata Sari Br Sembiring ${ }^{3}$, Patricia \\ Intan Karonesia Br Tarigan ${ }^{4}$, Vini Alvionita Br Sitepu ${ }^{5}$ \\ Pendidikan Ekonomi \\ Uninersitas Negeri Medan \\ Email : intanpermatasaribrsembiring@gmail.com
}

\begin{abstract}
Abstrak
Budaya konsumerisme dianggap sebagai budaya yang harus melekat pada masyarakat seolaholah untuk memperoleh sebuah identitas maka mereka harus memilih sebuah gaya hidup yang menganut kepada budaya konsumerisme. Penelitian ini bertujuan untuk mengetahui bagaimana budaya konsumerisme dikalangan mahasiswa universitas negeri medan prodi pendidikan ekonomi stambuk 2018. Teknik pengambilan sampel menggunakan Total Sampling. Data diperoleh melalui angket secara online menggunakan media google form. metode analisis data yang digunakan dalam penelitian ini adalah analisis deskriptif. Dari penelitian yang dilakukan diperoleh hasil bahwa ada budaya konsumerisme dikalangan mahasiswa universitas negeri medan prodi pendidikan ekonomi stambuk 2018. Hal ini terlihat bahwa kadang-kadang mahasiswa universitas negeri medan prodi pendidikan ekonomi stambuk 2018 membeli sesuatu secara berlebihan tanpa memikirkan kebutuhan
\end{abstract}

Kata Kunci: Budaya Konsumerisme, Mahasiwa

\section{PENDAHULUAN}

\section{Latar Belakang}

Globalisasi membawa banyak perubahan di dalam kehidupan manusia seperti pola hidup, pengetahuan, budaya, adat istiadat, dan sebagainya. Pola hidup masyarakat yang awalnya berbelanja untuk memenuhi kebutuhan hidupnya berubah menjadi berbelanja melebihi kebutuhannya, yang sering disebut sebagai konsumerisme. Konsumerisme ini hampir dialami oleh seluruh lapisan masyarakat termasuk dikalangan mahasiswa. Jamil, Dkk (2018) menyatakan bahwa 
Perubahan paling mendasar di abad globalisasi ini adalah perubahan ke arah masyarakat konsumer yang menciptakan budaya konsumeris dan gaya hidup konsumerisme. Di dalamnya terdapat sebuah konsep kapitalisme. Sebuah kondisi yang di dalamnya hampir seluruh energi dipusatkan bagi pelayanan hawa nafsu, nafsu kebendaan, kekayaan, kekuasaan, seksual, ketenaran, popularitas, kecantikan, kebugaran, keindahan, kesenangan sementara hanya menyisakan sedikit ruang bagi penajaman hati, penumbuhan kebijaksanaan, peningkatan kesalehan, dan pencerahan spiritual.

Gaya hidup masyarakat di zaman sekarang sudah mengikuti gaya hidup modern yang dapat dilihat dari cara mengenakan barang yang bermerek atau barang yang trend, seperti ponsel, baju, aksesoris, dan lain sebagainya. Budaya konsumerisme dianggap sebagai budaya yang harus melekat pada masyarakat seolah-olah untuk memperoleh sebuah identitas maka mereka harus memilih sebuah gaya hidup yang menganut kepada budaya konsumerisme. Sebuah gengsi menjadi panutan utama dalam pola konsumsi sehingga akan menghasilkan konsumerisme. Sehingga gaya hidup yang seperti itu menjadi bagian dari manusia yang tidak dapat dipisahkan dari kehidupannya. Octaviana, Rina (2020).

Fenomena perilaku konsumtif mahasiswa adalah perilaku yang mencerminkan "serba instan" atau perilaku yang tidak mengindahkan proses, bahkan tidak peduli dengan proses. Kebutuhan mahasiswa dewasa ini bukan sekadar UKT (Uang Kuliah Tunggal) dan finansial semata, tetapi juga kebutuhan lain untuk menunjang penampilan dan gengsinya. Bahkan, konsumtif cenderung mengarah pada gaya hidup glamor, boros, dan hedon. Perilaku konsumtif ini kemudian dianggap lazim dialami pada masa-masa remaja, terutama pada mahasiswa. Remaja terkesan senang dengan perilaku yang berbau konsumtif dan hedon (kesenangan/kenikmatan). Rohman, A. (2016).

\section{Rumusan Masalah}

Berdasarkan fenomena diatas maka rumusan masalah dalam penelitian ini adalah, bagaimana budaya konsumerisme dikalangan mahasiswa universitas negeri medan prodi pendidikan ekonomi stambuk 2018. 


\section{Tujuan Penelitian}

Berdasarkan rumusan masalah diatas maka tujuan penelitian ini adalah untuk mengetahui bagaimana budaya konsumerisme dikalangan mahasiswa universitas negeri medan prodi pendidikan ekonomi stambuk 2018.

\section{TINJAUAN PUSTAKA}

\section{Perilaku Konsumtif}

Menurut Kamus Besar Bahasa Indonesia, perilaku dapat diartikan sebagai tanggapan atau reaksi individu terhadap rangsangan atau lingkungan. Sedangkan perilaku konsumtif artinya bersifat konsumsi (hanya memakai, tidak menghasilkan sendiri). Dalam bahasa inggris kata konsumtif digunakan untuk menyatakan penggunaan sesuatu hal dengan berlebihan memboroskan, obsesif dan rakus. Definisi lain disampaikan oleh Lubis dalam (Sumartono, 2002) perilaku konsumtif merupakan perilaku membeli yang tidak didsarkan pada pertimbangan yang rasional, melakinkan karena adanya keinginan yang sudah mencapai taraf yang tidak rasional lagi. Sedangkan Yayasan Lembaga Konsumen Indonesia mengatakan perilaku konsumtif merupakan kecenderungan individu untuk mengonsumsi sesuatu tanpa batasan dan hanya mementingkan faktor keinginan

(Swasta \& Hani, 2011) menyatakan bahwa dalam mendeskripsikan perilaku konsumtif maka konsumen tidak dapat lagi membedakan antara kebutuhannya dan keinginannya.

(Hidayah, 2015) menjelaskan perilaku konsumtif merupakan perilaku dimana timbulnya keinginan untuk membeli suatu barang yang kurang diperlukan untuk memenuhi kepuasan pribadi. Dalam psikologi, hal ini dikenal dengan istilah compulsive buying disorder (kecanduan belanja), dimana orang yang terjebak di dalamnya tidak bisa membedakan mana kebutuhan dan keinginan.

Berdasarkan pendapat dari beberapa ahli diatas, dapat disimpulkan bahwa perilaku konsumtif merupakan suatu tindakan atau perilaku seseorang untuk membeli serta menggunakan barang ataupun jasa secara berlebihan tanpa adanya pemikiran yang matang dengan tujuan untuk memenuhi keinginan pribadi semata 
dan bukan berdasarkan kebutuhan dasar atau pokok dalam rangka memenuhi gaya hidup dan pemenuhan gengsi semata.

\section{Faktor Penyebab Terjadinya Perilaku Konsumtif}

Dewasa ini, perilaku konsumtif telah melanda semua kalangan masyarakat, salah satunya adalah kaum remaja dimana termasuk kedalamnya adalah seorang mahasiswa. (Santrock, 2012) menjelaskan pada masa remaja, seseorang akan cenderung menyukai berbagai hal baru yang cukup menantang bagi dirinya, hal tersebut dikarenakan remaja berupaya untuk mencapai kemandirian dan menemukan identitas dalam dirinya.

Remaja berperilaku konsumtif karena ingin menjaga gengsi, atau ingin membuat dirinya terlihat lebih baik dibanding orang lain (Burns, 1993).

Seseorang yang memiliki perilaku konsumtif biasanya disebabkan oleh beberapa faktor sebagaimana dikemukakan oleh (Kotler \& Keller, 2000) :

a. Faktor budaya

Faktor budaya merupakan hal yang sangat penting dalam perilaku pembelian yang mana faktor budaya ini terdiri dari budaya dan kelas sosial. Budaya merupakan penentu keinginan dan perilaku yang paling dasar. Kelas social adalah pembagian dalam masyarakat yang relatif homogen dan permanen, yang tersusun secara hirarkis dan yang para anggotanya menganut nilai, minat, dan perilaku yang serupa.

b. Faktor sosial

Dipengaruhi oleh kelompok acuan, keluarga, dan status sosial. Kelompok acuan adalah seseorang terdiri dari semua kelompok yeng memiliki pengaruh langsung atau tidak langsung terhadap sikap atau perilaku seseorang tersebut. Keluarga merupakan organisasi pembelian konsumen yang paling penting dalam masyarakat, dan anggota para keluarga menjadi kelompok acuan primer yang paling berpengaruh. Peran dan tatus sosial adalah peran meliputi kegiatan yang diharapkan akan dilakukan oleh seseorang, masing-masing peran menghasilkan status. 


\section{c. Faktor Pribadi}

Usia dan tahap siklus hidup, orang membeli barang dan jasa berbeda-beda sepanjang hidupnya. Adapun yang mempengaruhi seseorang dalam membeli atau mengkonsumsi barang dan jasa, yaitu pekerjaan dan lingkungan ekonomi, gaya hidup, pola hidup seseorang di dunia yang terungkap pada aktivitas, minat dan opininya, serta kepribadian dan konsep diri. Kepribadian adalah ciri bawaan psikologi manusia yang terbedakan yang manghasilkan tanggapan yang relatif konsisten dan bertahan lama terhadap rangsangan lingkungannya.

d. Faktor psikologis

Dimana didalamnya terdapat motivasi, persepsi, dan sikap. Motivasi, muncul karena adanya kebutuhan yang dirasakan oleh konsumen, kebutuhan sendiri muncul karena konsumen merasakan ketidak nyamanan antara yang seharusnya dirasakan dan yang sesungguhnya dirasakan. Kebutuhan yang dirasakan tersebut mendorong seseorang untuk melakukan tindakan untuk memenuhi kebutuhan tersebut. Artinya, motivasi adalah daya dorong yang muncul dari seorang konsumen yang akan mempengaruhi proses keputusan konsumen dalam membeli dan menggunakan barang dan jasa.

Budaya konsumerisme ini juga ditandai dengan beberapa aspek sebagaimana yang terdapat dalam (Lina \& Rosyid, 1999) :

a) Pembelian implusif (implusive buying)

Dalam aspek ini menunjukkan bahwa seseorang yang melakukan pembelanjaan atau pembelian semata-mata hanya karena nafsu atau hasrat yang tiba-tiba muncul atau keinginan yang bersifat sesaat, kemudian pembelanjaan terjadi tanpa mempertimbangkannya terlebih dahulu biasanya bersifat emosional, tanpa memikirkan lagi apa yang akan terjadi setelahnya.

b) Pemborosan (Wasteful Buying)

Perilaku konsumtif adalah suatu bentuk perilaku yang hanya menghamburhamburkan banyak dana tanpa di dasari adanya kebutuhan yang jelas serta perilaku membeli yang tidak hanya satu barang tapi lebih dari satu barang. 
c) Mencari Kesenangan (Non Rational Buying)

Suatu perilaku dimana konsumen membelli sesuatu yang dilakukan semata-mata untuk mencari kesenangan dan kepuasan serta konsumen membelikarena faktor hobi. Para remaja yang melakukan perilaku konsumtif dilatar belakangi oleh sifat remaja yang merasa senang saat memakai barang yang dapat membedakannya dari yang lainnya.

\section{Karakteristik Perilaku Konsumtif}

Seseorang yang memiliki perilaku konsumtif biasanya memilki ciri-ciri atau karakteristik sebagaimana dikemukakan oleh (Widyaningrum \& Puspitadewi, 2016).

1) Mudah terbujuk rayuan dari penjual.

2) Punya perasaan tidak enak pada penjual.

3) Tidak sabar jika ingin membeli barang, sehingga dalam membeli barang tidak berdasarkan banyak pertimbangan dan hanya karena keinginan sesaat.

\section{METODOLOGI PENELITIAN}

\section{Ruang Lingkup Penelitian}

Penelitian ini dilakukan kepada Mahasiswa Universitas Negeri Medan Prodi Pendidikan Ekonomi Stambuk 2018 dengan cara menyebarkan kuesioner secara online menggunakan media google form. Penelitian ini menguunakan metode kualitatif. Data yang muncul dalam penelitian kualitatif ini berbentuk kata-kata, dan bukan rangkaian angka. Cara-cara yang digunakan peneliti untuk memperoleh data adalah dengan memberikan angket.

\section{Populasi dan Sampel}

Populasi adalah keseluruhan objek penelitian apabila seseorang ingin meneliti semua elemen yang ada didalam wilayah penelitian, maka penelitianya merupakan penelitian populasi (Arikunto, 2006). Populasi dalam penelitian adalah Mahasiswa Prodi Pendidikan Ekonomi Stambuk 2018 Fakultas Ekonomi Universitas Negeri Medan. 
Pengampilan sampel pada penelitian ini menggunakan Total Sampling, yang berarti sampel dari penelitian ini adalah keseluruhan mahasiswa Universitas Negeri Medan Prodi Pendidikan Ekonomi Stambuk 2018 yang jumlahnya sebanyak 101 responden.

\section{Sumber dan Jenis Data}

Data yang digunakan dalam penelitian ini adalah data Primer. Data tersebut diperoleh melalui kuisioner/angket. Kuisioner adalah pengumpulan data dengan memberikan daftar pertanyaan kepada responden (Mahasiswa Universitas Negeri Medan Prodi Pendidikan Ekonomi Stambuk 2018).

\section{Instrumen Penelitian}

Instrumen yang digunakan dalam penelitian ini adalah angket, sejumlah pernyataan tertulis yang digunakan untuk memperoleh informasi dari responden. Melalui angket ini, dikumpulkan informasi mengenai budaya konsumerisme di kalangan mahasiswa studi kasus pada Mahasiswa Universitas Negeri Medan Prodi Pendidikan Ekonomi Stambuk 2018.

Jumlah soal yang tertera dalam angket adalah 7 pertanyaan dimana setiap pertanyaan diberi 5 (lima) pilihan dengan kisi-kisi sebagai berikut :

\begin{tabular}{|c|c|c|c|}
\hline No. & Variabel & Indikator & No. item pertanyaan \\
\hline \multirow{2}{*}{1.} & Perilaku Konsumtif & Hadiah & $1,2,3,4$ \\
\cline { 3 - 4 } & Produk menarik & 5,6 \\
\cline { 3 - 4 } & Gengsi & $7,8,9$ \\
\cline { 3 - 4 } & Penilaian orang & 10,11 \\
\cline { 3 - 4 } & Artis iklan & $12,13,14$ \\
\cline { 3 - 4 } & Produk mahal & $15,16,17$ \\
\cline { 3 - 4 } & Produk sejenis & $18,19,20$ \\
\hline
\end{tabular}

\section{Metode Analisis Data}

Dalam penelitian ini metode analisis data yang digunakan dalam penelitian ini adalah analisis deskriptif. Metode analisis deskriptif merupakan metode yang 
digunakan untuk menyajikan data kuantitatif dalam bentuk deskriptif. Analisis deskriptif menggambarkan atau mendeskripsikan data dengan apa adanya.

\section{HASIL DAN PEMBAHASAN}

\section{Hasil Penelitian}

Berdasarkan hasil angket dapat diamati budaya konsumenrisme dikalangan mahasiswa Universitas Negeri Medan Fakultas Ekonomi Prodi Pendidikan Ekonomi Stambuk 2018 melalui indikator yang terdapat pada instrument, sebagai berikut :

1. Saya akan membeli suatu produk apabila disertai dengan potongan harga dan pemberian hadiah (bonus) tertentu

Distibusi frekuensi masing-masing jawaban mahasiswa Universitas Negeri Medan Fakultas Ekonomi Prodi Pendidikan Ekonomi Stambuk 2018 ditampilkan pada table 4.1.1

Tabel 4.1.1 Respon mahasiswa terhadap item soal 1

\begin{tabular}{lc}
\hline \multicolumn{1}{c}{ Pilihan } & \% \\
\hline Selalu & 20,7 \\
Sering & 35,9 \\
Kadang-kadang & 38 \\
Jarang & 4,3 \\
Tidak pernah & 1,1 \\
TOTAL & 100 \\
\hline
\end{tabular}

Berdasarkan tabel diatas diperoleh bahwa sebagaian besar mahasiswa akan membeli suatu produk apabila disertai dengan potongan harga dan pemberian hadiah (bonus) tertentu dengan pilihan "selalu" sebanyak 20,7\%, "sering" sebanyak 35,9\%, "kadang-kadang" sebanyak 38\%, "jarang" sebanyak 4,3\%, dan “tidak pernah" sebanyak 1,1\%. 
2. Saya membeli sesuatu produk karena saya suka dengan hadiah yang ditawarkan.

Distibusi frekuensi masing-masing jawaban mahasiswa Universitas Negeri Medan Fakultas Ekonomi Prodi Pendidikan Ekonomi Stambuk 2018 ditampilkan pada table 4.1.2

Tabel 4.1.2 Respon mahasiswa terhadap item soal 2

\begin{tabular}{lc}
\hline \multicolumn{1}{c}{ Pilihan } & \% \\
\hline Selalu & 15,2 \\
Sering & 16,3 \\
Kadang-kadang & 45,7 \\
Jarang & 18,5 \\
Tidak pernah & 4,3 \\
TOTAL & 100 \\
\hline
\end{tabular}

Berdasarkan tabel diatas diperoleh bahwa sebagaian besar mahasiswa akan membeli sesuatu produk karena saya suka dengan hadiah yang ditawarkan dengan pilihan "selalu" sebanyak 15,2\%, "sering" sebanyak 16,3\%, "kadangkadang" sebanyak 45,7\%, "jarang” sebanyak 18,5\%, dan “tidak pernah" sebanyak $4,3 \%$.

3. Saya membeli produk jika beli 1 gratis 1 .

Distibusi frekuensi masing-masing jawaban mahasiswa Universitas Negeri Medan Fakultas Ekonomi Prodi Pendidikan Ekonomi Stambuk 2018 ditampilkan pada table 4.1.3

Tabel 4.1.3 Respon mahasiswa terhadap item soal 3

\begin{tabular}{lc}
\hline \multicolumn{1}{c}{ Pilihan } & \% \\
\hline Selalu & 19,6 \\
Sering & 29,3 \\
Kadang-kadang & 39,1 \\
Jarang & 10,9 \\
Tidak pernah & 1,1 \\
TOTAL & 100 \\
\hline
\end{tabular}


Berdasarkan tabel diatas diperoleh bahwa sebagaian besar mahasiswa akan membeli produk jika beli 1 gratis 1 dengan pilihan "selalu" sebanyak 19,6\%, “sering" sebanyak 29,3\%, "kadang-kadang" sebanyak 39,1\%, "jarang" sebanyak $10,9 \%$, dan "tidak pernah" sebanyak $1,1 \%$.

4. Ketika ada promo seperti diskon, gratis ongkir, flashsale, flashdeal, dan lainnya, saya akan langsung membelinya

Distribusi frekuensi masing-masing jawaban mahasiswa Universitas Negeri Medan Fakultas Ekonomi Prodi Pendidikan Ekonomi Stambuk 2018 ditampilkan pada table 4.1.4

Tabel 4.1.4 Respon mahasiswa terhadap item soal 4

\begin{tabular}{lc}
\hline \multicolumn{1}{c}{ Pilihan } & \% \\
\hline Selalu & 18,5 \\
Sering & 32,6 \\
Kadang-kadang & 35,9 \\
Jarang & 13 \\
Tidak pernah & 0 \\
TOTAL & 100 \\
\hline
\end{tabular}

Berdasarkan tabel diatas diperoleh bahwa sebagian besar mahasiswa akan membeli produk ketika ada promo seperti diskon, gratis ongkir dengan pilihan "selalu" sebanyak 18,5\%, "sering" sebanyak 32,6\%, "kadang-kadang" sebanyak $35,9 \%$, “jarang” sebanyak $13 \%$.

\section{Saya lebih memperhatikan aspek gaya atau status sosial dalam memutuskan pembelian produk}

Distibusi frekuensi masing-masing jawaban mahasiswa Universitas Negeri Medan Fakultas Ekonomi Prodi Pendidikan Ekonomi Stambuk 2018 ditampilkan pada table 4.1 .5 
Tabel 4.1.5 Respon mahasiswa terhadap item soal 5

\begin{tabular}{lc}
\hline \multicolumn{1}{c}{ Pilihan } & $\%$ \\
\hline Selalu & 10,9 \\
Sering & 16,3 \\
Kadang-kadang & 32,6 \\
Jarang & 23,9 \\
Tidak pernah & 16,3 \\
TOTAL & 100 \\
\hline
\end{tabular}

Berdasarkan tabel diatas diperoleh bahwa sebagaian besar mahasiswa lebih memperhatikan aspek gaya atau status sosial dalam memutuskan pembelian produk dengan pilihan "selalu" sebanyak 10,9\%, "sering" sebanyak 16,3\%, "kadang-kadang" sebanyak 32,6\%, "jarang" sebanyak 23,9\%, dan "tidak pernah" sebanyak $16,3 \%$.

6. Saya membeli suatu barang karena packaging produknya yang menarik

Distibusi frekuensi masing-masing jawaban mahasiswa Universitas Negeri Medan Fakultas Ekonomi Prodi Pendidikan Ekonomi Stambuk 2018 ditampilkan pada table 4.1 .6

Tabel 4.1.6 Respon mahasiswa terhadap item soal 6

\begin{tabular}{lc}
\hline \multicolumn{1}{c}{ Pilihan } & $\%$ \\
\hline Selalu & 9,8 \\
Sering & 15,2 \\
Kadang-kadang & 43,5 \\
Jarang & 22,8 \\
Tidak pernah & 8,7 \\
TOTAL & 100 \\
\hline
\end{tabular}

Berdasarkan tabel diatas diperoleh bahwa sebagian besar mahasiswa akan membeli suatu barang karena packaging produknya yang menarik dengan pilihan 
"selalu" sebanyak 9,8\%, "sering" sebanyak 15,2\%, "kadang-kadang" sebanyak $43,5 \%$, "jarang" sebanyak 22,8\%, dan "tidak pernah" sebanyak 8,7\%.

\section{Saya merasa bangga ketika menggunakan produk mahal}

Distibusi frekuensi masing-masing jawaban mahasiswa Universitas Negeri Medan Fakultas Ekonomi Prodi Pendidikan Ekonomi Stambuk 2018 ditampilkan pada table 4.1.7

Tabel 4.1.7 Respon mahasiswa terhadap item soal 7

\begin{tabular}{lc}
\hline \multicolumn{1}{c}{ Pilihan } & \% \\
\hline Selalu & 6,5 \\
Sering & 16,3 \\
Kadang-kadang & 28,3 \\
Jarang & 23,9 \\
Tidak pernah & 25 \\
TOTAL & 100 \\
\hline
\end{tabular}

Berdasarkan tabel diatas diperoleh bahwa sebagaian besar mahasiswa akan merasa bangga ketika menggunakan produk mahal dengan pilihan "selalu" sebanyak 6,5\%, "sering" sebanyak 16,3\%, "kadang-kadang” sebanyak 28,3\%, “jarang” sebanyak 23,9\%, dan "tidak pernah" sebanyak $25 \%$.

8. Saya merasa setiap produk yang saya gunakan jauh lebih baik dibandingkan orang lain

Distibusi frekuensi masing-masing jawaban mahasiswa Universitas Negeri Medan Fakultas Ekonomi Prodi Pendidikan Ekonomi Stambuk 2018 ditampilkan pada table 4.1.8

Tabel 4.1.8 Respon mahasiswa terhadap item soal 8

\begin{tabular}{lc}
\hline \multicolumn{1}{c}{ Pilihan } & \% \\
\hline Selalu & 4,3 \\
Sering & 5,4 \\
Kadang-kadang & 35,9 \\
\hline
\end{tabular}




\begin{tabular}{lc}
\hline Jarang & 23,9 \\
Tidak pernah & 30,4 \\
TOTAL & 100 \\
\hline
\end{tabular}

Berdasarkan tabel diatas diperoleh bahwa sebagaian besar mahasiswa merasa setiap produk yang saya gunakan jauh lebih baik dibandingkan orang lain dengan pilihan "selalu" sebanyak 4,3\%, "sering" sebanyak 5,4\%, "kadangkadang” sebanyak 35,9\%, "jarang” sebanyak 23,9\%, dan “tidak pernah" sebanyak $30,4 \%$.

\section{Saya memakai barang bermerek agar terlihat lebih mewah dibandingkan orang lain}

Distibusi frekuensi masing-masing jawaban mahasiswa Universitas Negeri Medan Fakultas Ekonomi Prodi Pendidikan Ekonomi Stambuk 2018 ditampilkan pada table 4.1.9

Tabel 4.1.9 Respon mahasiswa terhadap item soal 9

\begin{tabular}{lc}
\hline \multicolumn{1}{c}{ Pilihan } & \% \\
\hline Selalu & 3,3 \\
Sering & 8,7 \\
Kadang-kadang & 19,6 \\
Jarang & 29,3 \\
Tidak pernah & 39,1 \\
TOTAL & 100 \\
\hline
\end{tabular}

Berdasarkan tabel diatas diperoleh bahwa sebagaian besar mahasiswa akan memakai barang bermerek agar terlihat lebih mewah dibandingkan orang lain dengan pilihan "selalu" sebanyak 3,3\%, "sering" sebanyak 8,7\%, "kadangkadang" sebanyak 19,6\%, "jarang" sebanyak 29,3\%, dan "tidak pernah" sebanyak $39,1 \%$. 
10. Saya suka membeli produk yang membuat penampilan saya menjadi terlihat keren dan fashionable dimata orang.

Distibusi frekuensi masing-masing jawaban mahasiswa Universitas Negeri Medan Fakultas Ekonomi Prodi Pendidikan Ekonomi Stambuk 2018 ditampilkan pada table 4.1 .10

Tabel 4.1.10 Respon mahasiswa terhadap item soal 10

\begin{tabular}{lc}
\hline \multicolumn{1}{c}{ Pilihan } & \% \\
\hline Selalu & 9,8 \\
Sering & 20,7 \\
Kadang-kadang & 31,5 \\
Jarang & 20,7 \\
Tidak pernah & 17,4 \\
TOTAL & 100 \\
\hline
\end{tabular}

Berdasarkan tabel diatas diperoleh bahwa sebagaian besar mahasiswa suka membeli produk yang membuat penampilan saya menjadi terlihat keren dan fashionable dimata orang dengan pilihan "selalu" sebanyak 9,8\%, "sering" sebanyak 20,7\%, "kadang-kadang” sebanyak 31,5\%, “jarang” sebanyak 20,7\%, dan "tidak pernah" sebanyak 17,4\%.

11. Saya membeli produk yang banyak digemari banyak orang.

Distibusi frekuensi masing-masing jawaban mahasiswa Universitas Negeri Medan Fakultas Ekonomi Prodi Pendidikan Ekonomi Stambuk 2018 ditampilkan pada table 4.1.11

Tabel 4.1.11 Respon mahasiswa terhadap item soal 11

\begin{tabular}{lc}
\hline \multicolumn{1}{c}{ Pilihan } & $\%$ \\
\hline Selalu & 6,5 \\
Sering & 16,3 \\
Kadang-kadang & 45,7 \\
Jarang & 26,1 \\
Tidak pernah & 5,4 \\
TOTAL & 100 \\
\hline
\end{tabular}


Berdasarkan tabel diatas diperoleh bahwa sebagaian besar mahasiswa akan membeli produk yang banyak digemari banyak orang dengan pilihan "selalu" sebanyak 6,5\%, "sering" sebanyak 16,3\%, "kadang-kadang" sebanyak 45,7\%, “jarang” sebanyak 26,1\%, dan "tidak pernah" sebanyak 5,4\%.

12. Saya tertarik memakai suatu produk karena artis (tokoh terkenal) yang memakai produk tersebut cantik atau tampan

Distibusi frekuensi masing-masing jawaban mahasiswa Universitas Negeri Medan Fakultas Ekonomi Prodi Pendidikan Ekonomi Stambuk 2018 ditampilkan pada table 4.1 .12

Tabel 4.1.12 Respon mahasiswa terhadap item soal 12

\begin{tabular}{lc}
\hline \multicolumn{1}{c}{ Pilihan } & $\%$ \\
\hline Selalu & 6,5 \\
Sering & 13 \\
Kadang-kadang & 29,3 \\
Jarang & 29,3 \\
Tidak pernah & 21,7 \\
TOTAL & 100 \\
\hline
\end{tabular}

Berdasarkan tabel diatas diperoleh bahwa sebagaian besar mahasiswa tertarik memakai suatu produk karena artis (tokoh terkenal) yang memakai produk tersebut cantik atau tampan dengan pilihan "selalu" sebanyak 6,5\%, "sering" sebanyak 13\%, "kadang-kadang" sebanyak 29,3\%, "jarang" sebanyak 29,3\%, dan "tidak pernah" sebanyak $21,7 \%$.

\section{Saya akan membeli produk yang di iklan oleh idola saya}

Distibusi frekuensi masing-masing jawaban mahasiswa Universitas Negeri Medan Fakultas Ekonomi Prodi Pendidikan Ekonomi Stambuk 2018 ditampilkan pada table 4.1 .13 
Tabel 4.1.13 Respon mahasiswa terhadap item soal 13

\begin{tabular}{lc}
\hline \multicolumn{1}{c}{ Pilihan } & \% \\
\hline Selalu & 2,2 \\
Sering & 18,5 \\
Kadang-kadang & 23,9 \\
Jarang & 22,8 \\
Tidak pernah & 32,6 \\
TOTAL & 100 \\
\hline
\end{tabular}

Berdasarkan tabel diatas diperoleh bahwa sebagaian besar mahasiswa akan membeli produk yang di iklan oleh idola nya dengan pilihan "selalu" sebanyak 2,2\%, "sering" sebanyak 18,5\%, "kadang-kadang" sebanyak 23,9\%, "jarang" sebanyak 22,8\%, dan "tidak pernah" sebanyak $32,6 \%$.

14. Saya akan membeli produk iklan yang cocok dikenakan oleh artis iklannya.

Distibusi frekuensi masing-masing jawaban mahasiswa Universitas Negeri Medan Fakultas Ekonomi Prodi Pendidikan Ekonomi Stambuk 2018 ditampilkan pada table 4.1 .14

Tabel 4.1.14 Respon mahasiswa terhadap item soal 14

\begin{tabular}{lc}
\hline \multicolumn{1}{c}{ Pilihan } & \% \\
\hline Selalu & 3,3 \\
Sering & 9,8 \\
Kadang-kadang & 22,8 \\
Jarang & 30,4 \\
Tidak pernah & 33,7 \\
TOTAL & 100 \\
\hline
\end{tabular}

Berdasarkan tabel diatas diperoleh bahwa sebagaian besar mahasiswa akan akan membeli produk iklan yang cocok dikenakan oleh artis iklannya. dengan pilihan "selalu" sebanyak 3,3\%, "sering" sebanyak 9,8\%, "kadang-kadang" sebanyak 22,8\%, “jarang” sebanyak 30,4\%, dan “tidak pernah" sebanyak 33,7\%. 
15. Saya merasa percaya diri ketika memakai barang dengan merek mahal

Distibusi frekuensi masing-masing jawaban mahasiswa Universitas Negeri Medan Fakultas Ekonomi Prodi Pendidikan Ekonomi Stambuk 2018 ditampilkan pada table 4.1 .15

Tabel 4.1.15 Respon mahasiswa terhadap item soal 15

\begin{tabular}{lc}
\hline \multicolumn{1}{c}{ Pilihan } & \% \\
\hline Selalu & 3,3 \\
Sering & 20,7 \\
Kadang-kadang & 37 \\
Jarang & 17,4 \\
Tidak pernah & 21,7 \\
TOTAL & 100 \\
\hline
\end{tabular}

Berdasarkan tabel diatas diperoleh bahwa sebagaian besar mahasiswa akan merasa percaya diri ketika memakai barang dengan merek mahal dengan pilihan “selalu" sebanyak 3,3\%, "sering" sebanyak 20,7\%, "kadang-kadang" sebanyak $37 \%$, “jarang” sebanyak 17,4\%, dan "tidak pernah" sebanyak $21,7 \%$.

16. Saya langsung yakin dengan kualitas produk jika produk memiliki harga yang mahal.

Distibusi frekuensi masing-masing jawaban mahasiswa Universitas Negeri Medan Fakultas Ekonomi Prodi Pendidikan Ekonomi Stambuk 2018 ditampilkan pada table 4.1 .16

Tabel 4.1.16 Respon mahasiswa terhadap item soal 16

\begin{tabular}{lc}
\hline \multicolumn{1}{c}{ Pilihan } & \% \\
\hline Selalu & 14,1 \\
Sering & 19,6 \\
Kadang-kadang & 41,3 \\
Jarang & 14,1 \\
Tidak pernah & 10,9 \\
TOTAL & 100 \\
\hline
\end{tabular}


Berdasarkan tabel diatas diperoleh bahwa sebagaian besar mahasiswa langsung yakin dengan kualitas produk jika produk memiliki harga yang mahal dengan pilihan "selalu" sebanyak 14,1\%, "sering" sebanyak 19,6\%, "kadangkadang" sebanyak 41,3\%, "jarang” sebanyak 14,1\%, dan "tidak pernah" sebanyak $10,9 \%$.

\section{Saya merasa senang ketika membeli salah satu produk mahal.}

Distibusi frekuensi masing-masing jawaban mahasiswa Universitas Negeri Medan Fakultas Ekonomi Prodi Pendidikan Ekonomi Stambuk 2018 ditampilkan pada table 4.1 .17

Tabel 4.1.17 Respon mahasiswa terhadap item soal 17

\begin{tabular}{lc}
\hline \multicolumn{1}{c}{ Pilihan } & \% \\
\hline Selalu & 9,8 \\
Sering & 21,7 \\
Kadang-kadang & 34,8 \\
Jarang & 20,7 \\
Tidak pernah & 13 \\
TOTAL & 100 \\
\hline
\end{tabular}

Berdasarkan tabel diatas diperoleh bahwa sebagaian besar mahasiswa merasa senang ketika membeli salah satu produk mahal dengan pilihan "selalu" sebanyak 9,8\%, "sering" sebanyak 21,7\%, "kadang-kadang” sebanyak 34,8\%, “jarang" sebanyak 20,7\%, dan "tidak pernah" sebanyak 13\%.

\section{Saya menggunakan lebih dari satu barang sejenis dengan merek} berbeda.

Distibusi frekuensi masing-masing jawaban mahasiswa Universitas Negeri Medan Fakultas Ekonomi Prodi Pendidikan Ekonomi Stambuk 2018 ditampilkan pada table 4.1.18. 
Tabel 4.1.18 Respon mahasiswa terhadap item soal 18

\begin{tabular}{lc}
\hline \multicolumn{1}{c}{ Pilihan } & \% \\
\hline Selalu & 7,6 \\
Sering & 21,7 \\
Kadang-kadang & 37 \\
Jarang & 18,5 \\
Tidak pernah & 15,2 \\
TOTAL & 100 \\
\hline
\end{tabular}

Berdasarkan tabel diatas diperoleh bahwa sebagaian besar mahasiswa menggunakan lebih dari satu barang sejenis dengan merek berbeda dengan pilihan "selalu" sebanyak 7,6\%, "sering" sebanyak 21,7\%, "kadang-kadang" sebanyak $37 \%$, “jarang” sebanyak 18,5\%, dan "tidak pernah" sebanyak 15,2\%.

19. Saya suka mengoleksi suatu barang yang saya suka meskipun fungsinya sama.

Distibusi frekuensi masing-masing jawaban mahasiswa Universitas Negeri Medan Fakultas Ekonomi Prodi Pendidikan Ekonomi Stambuk 2018 ditampilkan pada table 4.1.19.

Tabel 4.1.19 Respon mahasiswa terhadap item soal 19

\begin{tabular}{lc}
\hline \multicolumn{1}{c}{ Pilihan } & $\%$ \\
\hline Selalu & 7,6 \\
Sering & 17,4 \\
Kadang-kadang & 22,8 \\
Jarang & 29,3 \\
Tidak pernah & 22,8 \\
TOTAL & 100 \\
\hline
\end{tabular}

Berdasarkan tabel diatas diperoleh bahwa sebagaian besar mahasiswa suka mengoleksi suatu barang yang saya suka meskipun fungsinya sama dengan pilihan "selalu" sebanyak 7,8\%, "sering" sebanyak 17,4\%, "kadang-kadang" sebanyak $22,8 \%$, “jarang” sebanyak 29,3\%, dan “tidak pernah" sebanyak 22,8\%. 
20. Saya tidak memikirkan secara mendalam konsekuensi dari pembelian barang yang saya lakukan meskipun fungsinya sama

Distibusi frekuensi masing-masing jawaban mahasiswa Universitas Negeri Medan Fakultas Ekonomi Prodi Pendidikan Ekonomi Stambuk 2018 ditampilkan pada table 4.1 .20

Tabel 4.1.20 Respon mahasiswa terhadap item soal 20

\begin{tabular}{ll}
\hline Pilihan & $\%$ \\
\hline Selalu & 8,7 \\
Sering & 10,9 \\
Kadang-kadang & 29,3 \\
Jarang & 21,7 \\
Tidak pernah & 29,3 \\
TOTAL & 100 \\
\hline
\end{tabular}

Berdasarkan tabel diatas diperoleh bahwa sebagaian besar mahasiswa tidak memikirkan secara mendalam konsekuensi dari pembelian barang yang saya lakukan meskipun fungsinya sama dengan pilihan "selalu" sebanyak 8,7\%, “sering" sebanyak 10,9\%, "kadang-kadang" sebanyak 29,3\%, "jarang” sebanyak $21,8 \%$, dan "tidak pernah" sebanyak $29,3 \%$.

\section{Pembahasan}

1. Hasil penelitian menunjukkan bahwa ada kalanya mahasiswa pendidikan ekonomi UNIMED stambuk 2018 akan membeli suatu produk bila disertai dengan adanya potongan harga dan pemberian bonus (hadiah) tertentu. Hal ini dapat dilihat dari pilihan mahasiswa terhadap item skala likert "kadangkadang” yang menunjukkan angka sebesar $38 \%$.

2. Hasil penelitian menunjukkan bahwa ada kalanya mahasiswa pendidikan ekonomi UNIMED stambuk 2018 akan membeli suatu produk bila disertai dengan adanya hadiah yang ditawarkan. Hal ini dapat dilihat dari pilihan mahasiswa terhadap item skala likert "kadang-kadang” yang menunjukkan angka sebesar $45,7 \%$. 
3. Hasil penelitian menunjukkan bahwa ada kalanya mahasiswa pendidikan ekonomi UNIMED stambuk 2018 akan membeli suatu produk jika disertai dengan penawaran buy one get one. Hal ini dapat dilihat dari pilihan mahasiswa terhadap item skala likert "kadang-kadang” yang menunjukkan angka $39,1 \%$.

4. Hasil penelitian menunjukkan bahwa ada kalanya mahasiswa pendidikan ekonomi UNIMED stambuk 2018 akan membeli suatu produk bila disertai dengan adanya diskon, gratis ongkir, flashsale, flashdeal dll. Hal ini dapat dilihat dari pilihan mahasiswa terhadap item skala likert "kadang-kadang" yang menunjukkan angka sebesar 35,9\%.

5. Hasil penelitian menunjukkan bahwa ada kalanya mahasiswa pendidikan ekonomi UNIMED stambuk 2018 akan membeli suatu produk demi memperhatikan aspek gaya atau status sosial. Hal ini dapat dilihat dari pilihan mahasiswa terhadap item skala likert "kadang-kadang" yang menunjukkan angka sebesar $32,6 \%$.

6. Hasil penelitian menunjukkan bahwa ada kalanya mahasiswa pendidikan ekonomi UNIMED stambuk 2018 akan membeli suatu produk bila tampilan produk (packaging) yang ditawarkan menarik. Hal ini dapat dilihat dari pilihan mahasiswa terhadap item skala likert "kadang-kadang" yang menunjukkan angka sebesar $43,5 \%$.

7. Hasil penelitian menunjukkan bahwa ada kalanya mahasiswa pendidikan ekonomi UNIMED stambuk 2018 akan merasa bangga ketika menggunakan produk yang mahal. Hal ini dapat dilihat dari pilihan mahasiswa terhadap item skala likert "kadang-kadang” yang menunjukkan angka sebesar $28,3 \%$.

8. Hasil penelitian menunjukkan bahwa ada kalanya mahasiswa pendidikan ekonomi UNIMED stambuk 2018 merasa bahwa produk yang mereka gunakan jauh lebih baik dibandingkan orang lain. Hal ini dapat dilihat dari pilihan mahasiswa terhadap item skala likert "kadang-kadang” yang menunjukkan angka sebesar $35,9 \%$.

9. Hasil penelitian menunjukkan bahwa mahasiswa pendidikan ekonomi UNIMED stambuk 2018 tidak pernah memakai barang yang bermerek 
dengan tujuan agar terlihat lebih mewah dibanding orang lain. Hal ini dapat dilihat dari pilihan mahasiswa terhadap item skala likert "tidak pernah" yang menunjukkan angka sebesar 39,1\%.

10. Hasil penelitian menunjukkan bahwa ada kalanya mahasiswa pendidikan ekonomi UNIMED stambuk 2018 membeli suatu produk yang dapat membuat penampilannya menjadi keren dan fashionable dimata orang. Hal ini dapat dilihat dari pilihan mahasiswa terhadap item skala likert " $k a d a n g$ kadang” yang menunjukkan angka sebesar $31,5 \%$.

11. Hasil penelitian menunjukkan bahwa ada kalanya mahasiswa pendidikan ekonomi UNIMED stambuk 2018 akan membeli suatu produk bila produk tersebut banyak digemari oleh orang. Hal ini dapat dilihat dari pilihan mahasiswa terhadap item skala likert "kadang-kadang” yang menunjukkan angka sebesar $45,7 \%$.

12. Hasil penelitian menunjukkan bahwa ada kalanya bahkan terkadang jarang mahasiswa pendidikan ekonomi UNIMED stambuk 2018 akan membeli suatu produk hanya karena tertarik oleh artis yang memakai produk tersebut. Hal ini dapat dilihat dari pilihan mahasiswa terhadap item skala likert “kadang-kadang” dan "jarang” yang menunjukkan persentase angka yang sama yaitu sebesar 29,3\%.

13. Hasil penelitian menunjukkan bahwa ada mahasiswa pendidikan ekonomi UNIMED stambuk 2018 tidak pernah membeli produk hanya karena produk tersebut di iklankan oleh sang idola mereka . Hal ini dapat dilihat dari pilihan mahasiswa terhadap item skala likert "tidak pernah" yang menunjukkan angka sebesar 32,6\%.

14. Hasil penelitian menunjukkan bahwa mahasiswa pendidikan ekonomi UNIMED stambuk 2018 tidak pernah membeli produk hanya karena produk tersebut cocok dengan artis yang mengiklankannya. Hal ini dapat dilihat dari pilihan mahasiswa terhadap item skala likert "tidak pernah" yang menunjukkan angka sebesar $33,7 \%$.

15. Hasil penelitian menunjukkan bahwa ada kalanya mahasiswa pendidikan ekonomi UNIMED stambuk 2018 akan membeli suatu produk dengan merek yang mahal karena merasa percaya diri ketika memakainya. Hal ini 
dapat dilihat dari pilihan mahasiswa terhadap item skala likert "kadangkadang” yang menunjukkan angka sebesar 37\%.

16. Hasil penelitian menunjukkan bahwa ada kalanya mahasiswa pendidikan ekonomi UNIMED stambuk 2018 akan membeli suatu produk karena yakin dengan kualitas produk yang memiliki harga yang mahal. Hal ini dapat dilihat dari pilihan mahasiswa terhadap item skala likert "kadang-kadang" yang menunjukkan angka sebesar 41,3\%.

17. Hasil penelitian menunjukkan bahwa ada kalanya mahasiswa pendidikan ekonomi UNIMED stambuk 2018 merasa senang ketika membeli produk yang mahal. Hal ini dapat dilihat dari pilihan mahasiswa terhadap item skala likert “kadang-kadang” yang menunjukkan angka sebesar 34,8\%.

18. Hasil penelitian menunjukkan bahwa ada kalanya mahasiswa pendidikan ekonomi UNIMED stambuk 2018 akan menggunakan lebih dari satu barang sejenis dengan merek yang berbeda Hal ini dapat dilihat dari pilihan mahasiswa terhadap item skala likert “kadang-kadang” yang menunjukkan angka sebesar $37 \%$.

19. Hasil penelitian menunjukkan bahwa mahasiswa pendidikan ekonomi UNIMED stambuk 2018 jarang mengoleksi suatu barang dengan fungsi yang sama. Hal ini dapat dilihat dari pilihan mahasiswa terhadap item skala likert “jarang-jarang” yang menunjukkan angka sebesar 29,3\%.

20. Hasil penelitian menunjukkan bahwa ada kalanya bahkan hampir jarang mahasiswa pendidikan ekonomi UNIMED stambuk 2018 tidak memikirkan secara mendalam konsekuensi dari pembelian barang yang mereka lakukan. Hal ini dapat dilihat dari pilihan mahasiswa terhadap item skala likert “kadang-kadang” dan "jarang” yang menunjukkan besaran angka yang sama yaitu sebesar 29,3\%.

\section{KESIMPULAN}

1. Berdasarkan jawaban item soal 1, 2, 3 dan 4 dapat disimpulkan bahwa dengan adanya hadiah mahasiswa Universitas Negeri Medan Prodi 
Pendidikan Ekonomi stambuk 2018 kadang - kadang akan membeli barang yang ditawarkan.

2. Berdasarkan jawaban item soal 5 dan 6 dapat disimpulkan bahwa jika produk menarik maka mahasiswa Universitas Negeri Medan Prodi Pendidikan Ekonomi stambuk 2018 kadang - kadang akan membeli barang yang ditawarkan.

3. Berdasarkan jawaban item soal 7,8 dan 9 dapat disimpulkan bahwa dengan gengsi yang dimiliki mahasiswa Universitas Negeri Medan Prodi Pendidikan Ekonomi stambuk 2018 kadang - kadang akan membeli barang yang ditawarkan.

4. Berdasarkan jawaban item soal 10 dan 11 dapat disimpulkan bahwa dengan memikirkan penilaian orang lain mahasiswa Universitas Negeri Medan Prodi Pendidikan Ekonomi stambuk 2018 kadang - kadang akan membeli barang yang ditawarkan.

5. Berdasarkan jawaban item soal 12, 13 dan 14 dapat disimpulkan bahwa mahasiswa Universitas Negeri Medan Prodi Pendidikan Ekonomi stambuk 2018 kadang - kadang akan membeli barang yang ditawarkan berdasarkan artis yang mengiklankannya.

6. Berdasarkan jawaban item soal 15, 16 dan 17 dapat disimpulkan bahwa jika produk mahal maka mahasiswa Universitas Negeri Medan Prodi Pendidikan Ekonomi stambuk 2018 kadang - kadang akan membeli barang yang ditawarkan.

7. Berdasarkan jawaban item soal 18, 19 dan 20 dapat disimpulkan bahwa mahasiswa Universitas Negeri Medan Prodi Pendidikan Ekonomi stambuk 2018 kadang - kadang membeli produk yang sejenis.

\section{SARAN}

Saran yang dapat penulis berikan sehingga kiranya dapat membantu dan bermanfaat adalah, semoga penelitian selanjutnya dapat menambah variabel lain didalam penelitian dan menambahkan indikator serta item pertanyaan yang lebih baik dan menarik. Bagi mahasiswa diharap dapat lebih bijak dalam mengelola 
uang dan bijak dalam pembelian barang yang dilakukan, sehingga tidak menumbuhkan budaya konsumerisme. Selain itu diharapkan agar orang kiranya orang tua dapat membantu para anak-anaknya dalam mengelola keuangan sehingga dapat bijak dalam membeli atau memutuskan dalam hal membeli dan mengkonsumsi suatu barang.

\section{DAFTAR PUSTAKA}

Arikunto, Suharsimi. 2006. Prosedur Penelitian. Jakarta: Rineka Cipta.

Jamil, Dkk. 2018. Perilaku Konsumeris Pengunjung Mall Lippo Plaza Kota Kendari. Neo Societal. Vol. 3; No. 2

Octaviana, Rina. 2020. Konsumeris Masyarakat Modern Dalam Kajian Herbert Marcuse. Jurnal Aqidah dan Filsafat Islam. Vol. 5; No. 1

Rohman, A. 2016. Budaya Konsumerisme dan Teori Kebocoran di Kalangan Mahasiswa. Jurnal Sosial dan Budaya Keislaman. Vol. 24 No. 2

Burns, R. . (1993). Konsep Diri: Teori, Pengukuran, Perkembangan dan Perilaku. Arcan.

Hidayah Rizika Witri. (2015). Perilaku Konsumtif Dalam Membeli Produk Fashion Pada Mahasiswa Putri Di Surakarta. Universitas Muhammadiyah Surakarta.

Kotler, P., \& Keller, K. L. (2000). Manajemen Pemasaran di Indonesia (edisi 1). Salembe Empat.

Lina, \& Rosyid, H. F. (1999). Perilaku Konsumtif Berdasar Locus Of Control Pada Remaja Putri. Psikologika, 4.

Santrock, J. W. (2012). Life Span Development: Perkembangan Masa Hidup (edisi ke-1). Erlangga.

Sumartono. (2002). Terperangkap Dalam Iklan. CV Alfabeta.

Sugiyono. 2010. Statistik Untuk Penelitian. Bandung: Alfabeta.

Swasta, D. B., \& Hani, H. (2011). Manajemen Pemasaran: Analisis Perilaku Konsumen Edisi 1. BPFE- Yogyakarta.

Widyaningrum, S., \& Puspitadewi, N. W. S. (2016). Perbedaan Perilaku Konsumtif Ditinjau dari Tipe Kepribadian Pada Siswa Sekolah Menengah Atas. Psikologi Teori Dan Terapan, 6(2). 


\title{
LAMPIRAN
}

Lampiran 1. Angket Penelitian

\author{
ANGKET PENELITIAN \\ BUDAYA KONSUMERISME DI KALANGAN MAHASISWA \\ UNIVERSITAS NEGERI MEDAN PRODI PENDIDIKAN EKONOMI \\ STAMBUK 2018
}

\section{Tanggal pengisian :}

\section{Identitas Responden :}
Nama :
Kelas :
Prodi :

Keterangan :

$$
\begin{array}{ll}
\text { STS } & =\text { Sangat Tidak Setuju } \\
\mathrm{TS} & =\text { Tidak Setuju } \\
\mathrm{KS} & =\text { Kurang Setuju } \\
\mathrm{S} & =\text { Setuju } \\
\mathrm{SS} & =\text { Sangat Setuju }
\end{array}
$$

Silahkan baca setiap pertanyaan berikut dan tunjuk dengan memberikan tanda centang $(\checkmark)$ pada kolom yang tersedia.

\begin{tabular}{|c|l|l|}
\hline Indikator & No. & \multicolumn{1}{|c|}{ Pertanyaan/pernyataan } \\
\hline 1. & 1 & $\begin{array}{l}\text { Saya akan membeli suatu produk apabila disertai dengan } \\
\text { potongan harga dan pemberian hadiah (bonus) tertentu }\end{array}$ \\
\hline & 2 & $\begin{array}{l}\text { Saya membeli sesuatu produk karena saya suka dengan hadiah } \\
\text { yang ditawarkan. }\end{array}$ \\
\hline & 3 & Saya membeli produk jika beli 1 gratis 1. \\
\hline
\end{tabular}




\begin{tabular}{|c|c|c|}
\hline & 4 & $\begin{array}{l}\text { Ketika ada promo seperti diskon, gratis ongkir, flashsale, } \\
\text { flashdeal, dan lainnya, saya akan langsung membelinya. }\end{array}$ \\
\hline \multirow[t]{2}{*}{2.} & 5 & $\begin{array}{l}\text { Saya lebih memperhatikan aspek gaya atau status sosial dalam } \\
\text { memutuskan pembelian produk }\end{array}$ \\
\hline & 6 & $\begin{array}{l}\text { Saya membeli suatu barang karena packaging produknya yang } \\
\text { menarik }\end{array}$ \\
\hline \multirow[t]{3}{*}{3.} & 7 & Saya merasa bangga ketika menggunakan produk mahal \\
\hline & 8 & $\begin{array}{l}\text { Saya merasa setiap produk yang saya gunakan jauh lebih baik } \\
\text { dibandingkan orang lain }\end{array}$ \\
\hline & 9 & $\begin{array}{l}\text { Saya memakai barang bermerek agar terlihat lebih mewah } \\
\text { dibandingkan orang lain }\end{array}$ \\
\hline \multirow[t]{2}{*}{4.} & 10 & $\begin{array}{l}\text { Saya suka membeli produk yang membuat penampilan saya } \\
\text { menjadi terlihat keren dan fashionable dimata orang. }\end{array}$ \\
\hline & 11 & Saya membeli produk yang banyak digemari banyak orang. \\
\hline \multirow[t]{3}{*}{5 . } & 12 & $\begin{array}{l}\text { Saya tertarik memakai suatu produk karena artis (tokoh terkenal) } \\
\text { yang memakai produk tersebut cantik atau tampan }\end{array}$ \\
\hline & 13 & Saya akan membeli produk yang di iklan oleh idola saya. \\
\hline & 14 & $\begin{array}{l}\text { Saya akan membeli produk iklan yang cocok dikenakan oleh } \\
\text { artis iklannya. }\end{array}$ \\
\hline \multirow[t]{3}{*}{6.} & 15 & $\begin{array}{l}\text { Saya merasa percaya diri ketika memakai barang dengan merek } \\
\text { mahal }\end{array}$ \\
\hline & 16 & $\begin{array}{l}\text { Saya langsung yakin dengan kualitas produk jika produk } \\
\text { memiliki harga yang mahal. }\end{array}$ \\
\hline & 17 & Saya merasa senang ketika membeli salah satu produk mahal. \\
\hline \multirow[t]{3}{*}{7.} & 18 & $\begin{array}{l}\text { Saya menggunakan lebih dari satu barang sejenis dengan merek } \\
\text { berbeda. }\end{array}$ \\
\hline & 19 & $\begin{array}{l}\text { Saya suka mengoleksi suatu barang yang saya suka meskipun } \\
\text { fungsinya sama. }\end{array}$ \\
\hline & 20 & $\begin{array}{l}\text { Saya tidak memikirkan secara mendalam konsekuensi dari } \\
\text { pembelian barang yang saya lakukan meskipun fungsinya sama }\end{array}$ \\
\hline
\end{tabular}

